\author{
Maria Użarowska, Magdalena Surman, Marcelina JANiK \\ Zakład Biochemii Glikokoniugatów \\ Instytut Zoologii i Badań Biomedycznych \\ Wydzial Biologii \\ Uniwersytet Jagielloński $w$ Krakowie \\ Gronostajowa 9, 30-387 Kraków \\ E-mail: maria.uzarowska@student.uj.edu.pl \\ magdalena.surman@doctoral.uj.edu.pl \\ marcelina.janik@uj.edu.pl
}

\title{
DWIE TWARZE CHOLESTEROLU: ZNACZENIE FIZJOLOGICZNE I UDZIAŁ W PATOGENEZIE WYBRANYCH SCHORZEŃ
}

\section{WSTEP}

Cholesterol to potoczna nazwa 5-cholesteno-3 $\beta$-olu, którego cząsteczka zbudowana jest $z$ 17-węglowej struktury cyklopentanoperhydrofenantrenu i dołaczonego do niej 6-węglowego łańcucha bocznego. Ze względu na obecność w cząsteczce jednej grupy hydroksylowej cholesterol klasyfikowany jest jako alkohol steroidowy. $\mathrm{W}$ organizmie człowieka występuje w osoczu krwi i tkankach zarówno w postaci wolnej, jak i zestryfikowanej kwasami tłuszczowymi. Cholesterol może być syntetyzowany de novo w watrobie i jelitach w szeregu reakcji enzymatycznych, lecz większa jego część dostarczana jest $z$ pokarmem i wchłaniana $\mathrm{w}$ jelicie cienkim. W organizmie człowieka zarówno cholesterol, jak i inne lipidy transportowane sa jako lipoproteiny, czyli w połaczeniu $z$ białkami. W tej postaci docieraja do komórek docelowych, gdzie w wyniku interakcji ze swoistymi receptorami zostaja wprowadzone do wnętrza komórki na drodze endocytozy (KONTUREK 2007).

Główną funkcją cholesterolu jest zależna od temperatury modulacja płynności błon komórkowych. W niskiej temperaturze chroni on błonę przed powstaniem fazy krystalicznej, podczas gdy w wysokiej zapobiega jej dezorganizacji. Duża ilość cholesterolu występuje w nanodomenach błonowych (np. tratwach lipidowych i kaweolach), które pełnią ważna rolę $\mathrm{w}$ procesie endocytozy i mię- dzykomórkowym przekazie sygnału (SoNG i współaut. 2014, PAILA i CHATTOPADHYAY 2010). Ponadto, jest on prekursorem hormonów steroidowych produkowanych przez gonady i korę nadnerczy (MILLER i AUCHUS 2011). Poza pełnieniem istotnej roli fizjologicznej, cholesterol może przyczyniać się do rozwoju stanów patologicznych, wynikających zarówno $z$ nagromadzenia jego czasteczek w ustroju, jak i zaburzeń w ich metabolizmie. Jego udział w patogenezie opisano m.in. w przypadku schorzeń neurodegeneracyjnych, chorób układu krażenia, chorób nerek i chorób nowotworowych.

\section{BUDOWA I BIOSYNTEZA CZĄTTECZKI CHOLESTEROLU}

Cholesterol jest typowym sterolem zbudowanym z 27 atomów węgla, zorganizowanych w cztery pierścienie (A-D): trzy sześciowęglowe $\mathrm{i}$ jeden pięciowęglowy. Pierścienie A i B moga łączyć się na dwa sposoby, tworząc konformację cis lub trans. Ułożenie pierścieni w konformacji cis jest charakterystyczne dla soli kwasów żółciowych, natomiast konformacja trans wystepuje w hormonach steroidowych, posiadajacych atom wodoru w pozycji $\mathrm{C}_{5}$. Klasyfikacja cholesterolu jako alkoholu wynika $z$ obecności w jego czasteczce grupy hydroksylowej $(-\mathrm{OH})$, dołaczonej do pierścienia A w pozycji $\mathrm{C}_{3}$ (Song i współaut. 2014). 


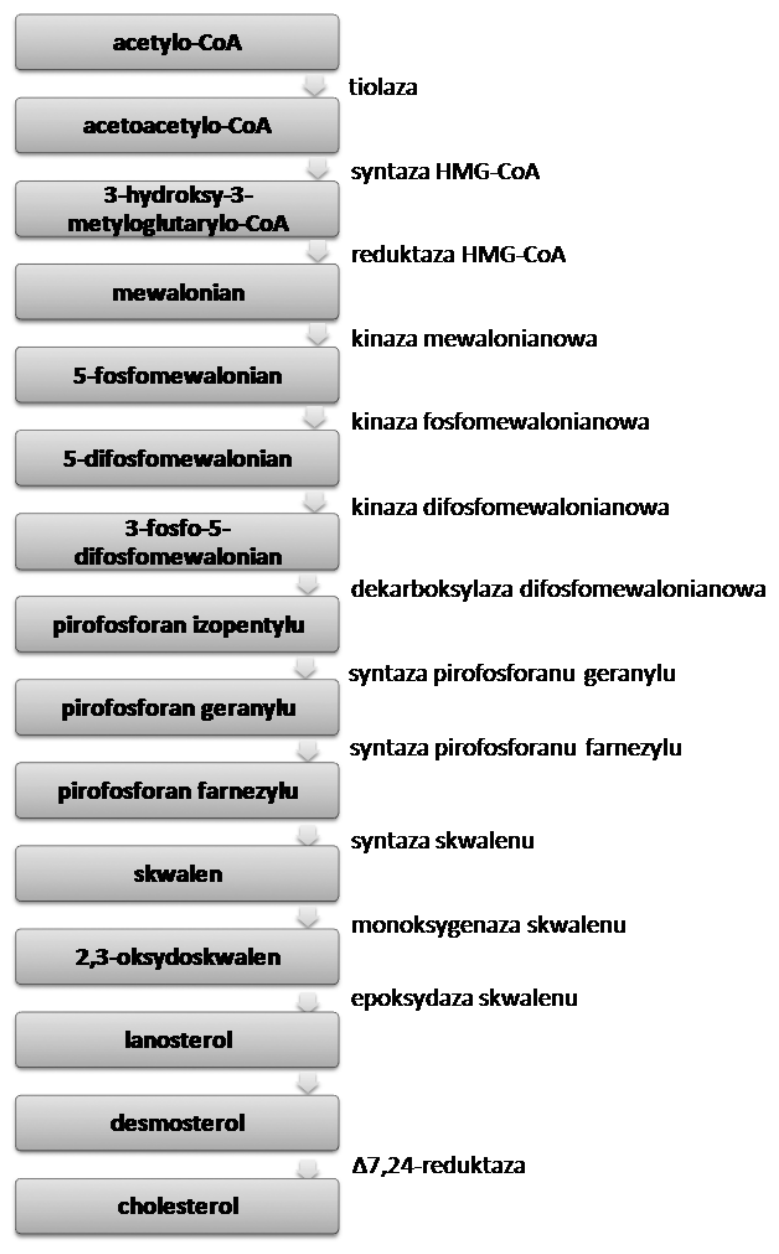

Ryc. 1. Schemat syntezy cholesterolu.

Optymalna ilość cholesterolu w organizmie człowieka jest uwarunkowana prawidłowym przebiegiem procesu jego biosyntezy (cholesterol endogenny) oraz zrównoważonym dostarczaniem ze źródeł egzogennych (pokarm). Cholesterol endogenny syntetyzowany jest głównie $\mathrm{w}$ wątrobie, jelitach i skórze. Powstaje $z$ acetylo-CoA, a jego tworzenie $z$ tej dwuwęglowej cząsteczki zachodzi w szeregu reakcji enzymatycznych przedstawionych na Ryc. 1 (Song i współaut. 2014). Szybkość syntezy cholesterolu ulega zmianom w cyklu okołodobowym oraz podlega regulacji hormonalnej. Zwiększenie aktywności kluczowych enzymów następuje w obecności insuliny lub hormonów tarczycy, natomiast spadek ich aktywności może być wynikiem działania glukagonu lub glikokortykosteroidów (MILLER i BOSE 2011).

\section{FORMY TRANSPORTOWE CHOLESTEROLU}

W organizmie człowieka większość lipidów, w tym cholesterol, jest transportowa- na w postaci lipoprotein, czyli kompleksów tworzonych $\mathrm{z}$ wyspecjalizowanymi białkami. Lipoproteiny to koliste struktury zbudowane $z$ hydrofobowego rdzenia i amfipatycznej powłoki zewnętrznej. Fragmenty białkowe, określane jako apolipoproteiny, pełnia podwójną rolę: umożliwiaja emulgację tłuszczów hydrofobowych i posiadaja fragmenty rozpoznawane przez komórki docelowe. Obecnie wyróżnia się 10 apolipoprotein (A-1, A-2, A-4, B-48, B-100, C-1, C-2, C-3, D i E), a każda $z$ nich jest syntetyzowana $i$ wydzielana przez wattrobę oraz jelito (STRYER 2003). Ze względu na zróżnicowana gęstość, lipoproteiny dzielimy na chylomikrony, lipoproteiny o bardzo małej gęstości (ang. very low-density lipoproteins, VLDL), lipoproteiny o pośredniej gęstości (ang. intermediate-density lipoproteins, IDL), lipoproteiny o małej gęstości (ang. low-density lipoproteins, LDL) i lipoproteiny o dużej gęstości (ang. highdensity lipoproteins, HDL) (STRYER 2003, DURRINGTON 2007). Wszystkie formy transportowe cholesterolu porównano w Tabeli 1.

\section{WCHŁANIANIE I KRAZŻENIE CHOLESTEROLU}

Duża część obecnego w organizmie człowieka cholesterolu dostarczana jest $z$ pokarmem. Endogenny cholesterol znajduje się w wyścielającym drogi pokarmowe, złuszczonym nabłonku i w wydzielanej przez watrobę żółci. Niezależnie od pochodzenia, wolna postać cholesterolu wchłaniana jest w proksymalnej części jelita cienkiego, a $z$ racji jego nierozpuszczalności $\mathrm{w}$ wodzie, proces ten zależny jest od obecności soli kwasów żółciowych (KONTUREK 2007).

Głównym źródłem cholesterolu w tkankach sa LDL, a jego pobieranie przez komórki docelowe jest procesem kilkuetapowym. Cząsteczka LDL wiąże się za pomoca apolipoproteiny B-100 ze specyficznym receptorem błonowym komórki docelowej, po czym kompleks LDL-receptor wnika do wnętrza komórki na drodze endocytozy. Powstałe pęcherzyki endocytarne ulegaja fuzji z lizosomami, gdzie dochodzi do hydrolizy komponentu białkowego do aminokwasów, a lipidowego do kwasów tłuszczowych i cholesterolu. Receptor LDL nie ulega hydrolizie, a po ponownej integracji $z$ zewnętrzna błona komórkowa może uczestniczyć w transporcie kolejnych czasteczek LDL. Uwolniony cholesterol zostaje wykorzystany do budowy błony komórkowej lub, po ponownym zestryfikowaniu, zmagazynowany $\mathrm{w}$ komórce (MESMIN i MAXFIELD 2009).

$\mathrm{Z}$ wchłoniętej $\mathrm{w}$ jelicie cienkim puli cholesterolu około $70 \%$ (jako składnik chylomikronów) trafia do naczyń limfatycznych, a 
Tabela 1. Klasyfikacja lipoprotein i ich udział w transporcie cholesterolu.

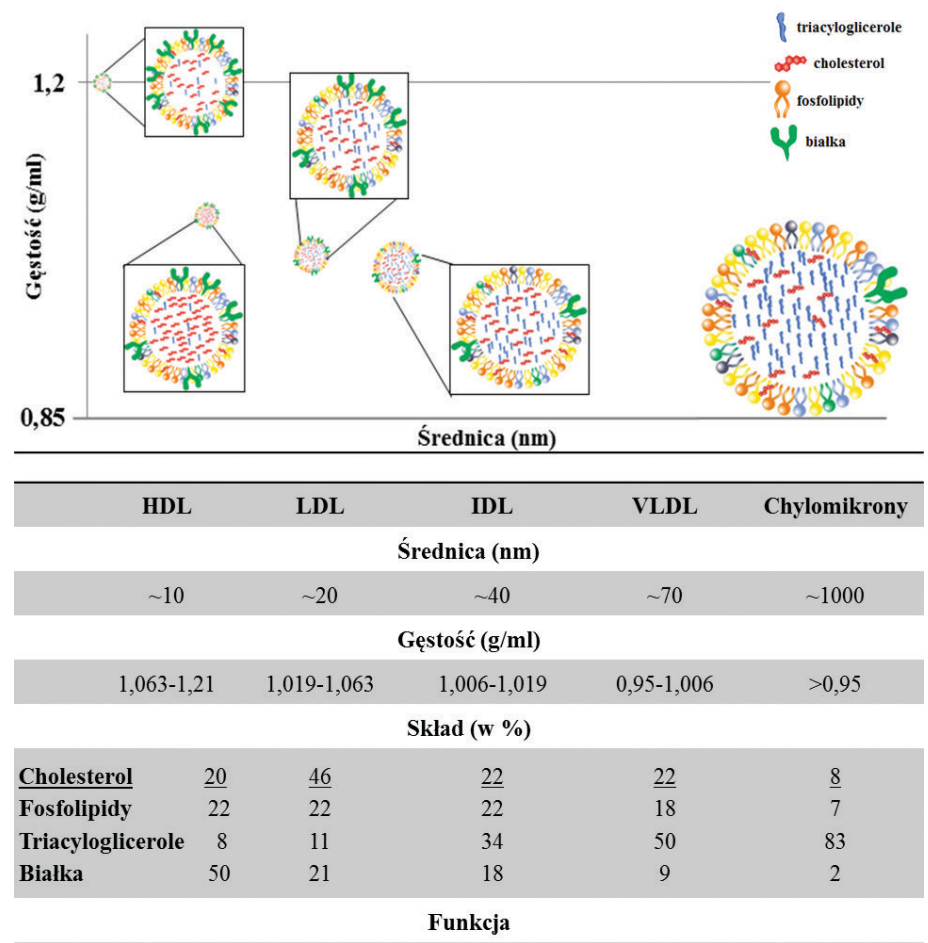

\begin{tabular}{|c|c|c|c|c|}
\hline $\begin{array}{c}\text { Gromadzenie i } \\
\text { estryfikacja z } \\
\text { udziałem } \\
\text { acylotransferazy } \\
\text { cholesterolu z osocza; } \\
\text { przerzucanie } \\
\text { cholesterolu do VLDL } \\
\text { i LDL; udzial w } \\
\text { odwróconym } \\
\text { transporcie } \\
\text { cholesterolu }\end{array}$ & $\begin{array}{c}\text { Transport } \\
\text { cholesterolu na } \\
\text { zasadzie } \\
\text { endocytozy } \\
\text { pęcherzyków do } \\
\text { wątroby i } \\
\text { innych tkanek } \\
\text { organizmu, } \\
\text { odbywającej się } \\
\text { z udziałem } \\
\text { specyficznych } \\
\text { receptorów }\end{array}$ & $\begin{array}{l}\text { Przemieszczanie } \\
\text { zawartości do } \\
\text { LDL lub } \\
\text { endocytoza do } \\
\text { komórek wątroby } \\
\text { z udziałem } \\
\text { specyficznych } \\
\text { receptorów }\end{array}$ & $\begin{array}{l}\text { Przemieszczanie } \\
\text { zawartości do } \\
\text { IDL i LDL; } \\
\text { hydroliza } \\
\text { triacylogliceroli } \\
\text { przy udziale } \\
\text { lipazy, } \\
\text { odbywająca się } \\
\text { w obrębie } \\
\text { naczyń } \\
\text { włosowatych }\end{array}$ & $\begin{array}{c}\text { Transport } \\
\text { triacylogriceroli } \\
\text { do wszystkich } \\
\text { tkanek oraz ich } \\
\text { hydroliza do } \\
\text { kwasów } \\
\text { thuszczowych } \\
\text { przez lipazę } \\
\text { lipoproteinową; } \\
\text { transport } \\
\text { cholesterolu do } \\
\text { wątroby }\end{array}$ \\
\hline
\end{tabular}

później do naczyń żylnych. Pozostała jego część jest odprowadzana żyła wrotna do watroby, skąd zostaje wydzielona wraz $z$ źółcią do dwunastnicy. W skład żółci wchodza mieszane micele, które, oprócz cholesterolu, zawierają sole żółciowe i fosfolipidy (KONTUREK 2007). Poziom cholesterolu w krażeniu podlega ścisłej kontroli poprzez mechanizm ujemnego sprzężenia zwrotnego, bowiem każde zmiany w jego stężeniu moga być przyczyna powstawania wielu chorób groźnych dla zdrowia i życia (SKOczYŃSKA 2005).

\section{FUNKCJE CHOLESTEROLU W KOMÓRCE}

\section{FORMOWANIE BŁON KOMÓRKOWYCH}

Wszystkie błony biologiczne maja wspólny plan budowy ogólnej, a jednocześnie szerokie spektrum wystepujacych w nich białek. Białka te moga być skutecznie zakotwiczone w błonie komórkowej, głównie dzięki zróżnicowaniu kształtu i właściwości fizycznych budujacych ja lipidów (BLOM i współaut. 2011). Lipidy, otaczając białka, zapewniaja błonie wysoką spójność, a każde patologiczne zmiany w składzie dwuwarstwy moga być przyczyna utraty jej funkcjonalności.

W strukturze błon biologicznych dominuja fosfolipidy (fosfatydylocholina, fosfatydyloseryna, fosfatydyloetanolamina, fosfatydyloinozytol, sfingomielina), cholesterol i glikolipidy. Fosfolipidy rozmieszczone sa w błonie w sposób asymetryczny (BLOM i współaut. 2011). Jednocześnie struktura dwuwarstwy lipidowej jest optymalna dla gospodarki energetycznej komórki. Umożliwia ona jednoczesne działanie dwóch antagonistycznych sił: przyciagania wody przez hydrofilowe 
"głowy" fosfolipidów i odpychania ich przez hydrofobowe "ogony”. Wodne środowisko po obu stronach błony zabezpiecza przed wydostawaniem się $z$ niej lipidów, nie uniemożliwia im jednak przemieszczania się $\mathrm{w}$ obrębie dwuwarstwy. Cecha ta, zwana płynnością błony, zależy od jej składu molekularnego, a głównym czynnikiem regulującym ja jest obecność cholesterolu (KANIA i współaut. 2012).

Czasteczki cholesterolu oddziałuja $z$ fosfolipidami poprzez ułożenie swoich polarnych grup -OH blisko hydrofilowych grup fosfolipidów. Sztywne pierścienie cholesterolu oddziałuja zaś $z$ hydrofobowymi łańcuchami kwasów tłuszczowych i częściowo usztywniaja je w miejscu zetknięcia "głów" z „ogonami”. W konsekwencji, cząsteczki lipidów sasiadujących $z$ cholesterolem maja ograniczona możliwość zmiany położenia $\mathrm{w}$ stosunku do lipidów w miejscach uboższych w cholesterol. Poprzez obniżenie mobilności znacznej liczby grup metylowych w „ogonach" kwasów tłuszczowych, cholesterol sprawia, że błona jest bardziej odporna na odkształcenia i wykazuje mniejsza przepuszczalność dla cząsteczek hydrofilowych. Co więcej, wpływ cholesterolu na płynność błony jest ściśle zwiazany $\mathrm{z}$ temperatura. W niskiej temperaturze uniemożliwia on łączenie się łańcuchów węglowodorowych i tworzenie fazy krystalicznej, natomiast w wysokiej temperaturze unieruchomienie grup metylowych w „ogonach” kwasów tłuszczowych zmniejsza płynność dwuwarstwy i zapobiega jej dezorganizacji (DE MEYer i SMit 2009).

\section{CHOLESTEROL JAKO SKŁADNIK TRATW LIPIDOWYCH I KAWEOLI}

Tratwy lipidowe, określane jako półsztywne nanodomeny $\mathrm{w}$ błonie komórkowej, to niewielkie jej obszary o odmiennym od pozostałych składzie białkowo-lipidowym. Zbudowane sa głównie $z$ glikosfingolipidów, sfingolipidów i cholesterolu (FEDORYSZAK-KUŚKA i współaut. 2011, Simons i SAMPAIO 2011, KANIA i współaut. 2012). W przypadku komórek tucznych i nabłonkowych, w obrębie tratw lipidowych zaobserwowano poziom cholesterolu przewyższający dwukrotnie jego średnia zawartość w całej błonie (KWIATKOWSKA i SOBOTA 2004). Uważa się jednak, że w tratwach lipidowych ilość czasteczek cholesterolu może wzrastać trzy, a nawet pięciokrotnie. Tratwy lipidowe odgrywaja istotna rolę $\mathrm{w}$ procesie endocytozy oraz uczestnicza w przekazywaniu sygnałów między komórkami. Ponadto, struktury te, znajdujace się w mózgu i zawierające dużą ilość cholesterolu, sa istotnym czynnikiem sprzyjającym i umożliwiającym rozwój chorób neurodegeneracyjnych, jak np. cho- roby Alzheimera (ang. Alzheimer's disease, AD) (KANIA i współaut. 2012).

Oprócz zewnętrzych błon komórkowych, tratwy lipidowe występuja również w błonach organelli wewnattrzkomórkowych, m.in. aparatu Golgiego, siateczki endoplazmatycznej i mitochondriów (KORDOWIAK i KORDOWIAK 2011). Domeny te charakteryzuja się wysoce uporząkowana struktura i nie rozpuszczaja się w detergentach (SONG i współaut. 2014). Osiagają różną wielkość; ich średnica najczęśsiej wynosi od 50 do 100 nm. Pomimo małych rozmiarów pojedynczej tratwy, ich suma może stanowić nawet 30\% powierzchni całej błony. Małe jednostki, w zależności od ich składu (głównie zawartości cholesterolu), moga łączyć się ze soba (tzw. koalescencja) i tworzyć większe frakcje, osiagajace nawet do $500 \mathrm{~nm}$ średnicy. Duże jednostki, zwane „klastrami”, zawieraja niewielką ilość cholesterolu i często zwiąane sa $z$ cytoszkieletem (KORDOWIAK i KORDOWIAK 2011, HEAD i współaut. 2014).

Okres półtrwania najmniejszych tratw lipidowych wynosi kilka milisekund, co wskazuje na wysoka dynamiczność tych struktur. Ich skład czasteczkowy ulega stałym zmianom, a funkcja tratw o tym samym składzie zależy od tego, czy znajdują się po cytoplazmatycznej (wewnętrznej), czy po zewnętrznej stronie dwuwarstwy. Cząsteczki budujące tratwy lipidowe moga ponadto przemieszczać się $z$ jednej strony błony na druga. Proces ten jest bardzo szybki i przebiega zwykle $\mathrm{w}$ czasie kilku nanosekund. Czynnikiem warunkujacym wspomniane zmiany położenia jest zawartość cholesterolu i innych lipidów w błonie (KORDOWIAK i KORDOWIAK 2011).

Tratwy lipidowe cechują się odmiennym składem części cytoplazmatycznej i zewnętrznej. W cytozolowej części tratw występuja głównie aminofosfolipidy (fosfatydyloetanolamina, fosfatydyloseryna), natomiast po stronie zewnętrznej cholesterol i sfingolipidy (KORDOWIAK i KORDOWIAK, 2011). W obrębie tratw lipidowych obserwuje się ścisłe upakowanie cholesterolu, co jest możliwe dzięki obecności w jego czassteczce nasyconych łańcuchów węglowodorowych. Zapewnia to większa hydrofobowość tych nanodomen w stosunku do obszarów błony nie zawierajacych tratw (SEBASTIAO i współaut. 2012).

Wyróżnia się dwie podstawowe formy tratw: płaskie oraz wpuklone do cytoplazmy, czyli kaweole. Różnica w budowie wynika $z$ odmiennego składu czassteczkowego i oddziaływań $z$ innymi organellami wewnątrzkomórkowymi. Dla tratw płaskich charakterystyczna sa obecność białka flotylliny, natomiast w tratwach wpuklonych do cytoplazmy znajdują się palmitoilowane białka, kaweoliny: kaweolina 1 (CAV-1), 2 (CAV-2) i 3 (CAV- 
3) (KORDOWIAK i KORDOWIAK 2011, KOVTUN i współaut. 2015, HEAD i współaut. 2014). Skład lipidowy kaweoli jest bardzo podobny do składu tratw (GBUREK i współaut. 2015), jednak wyższa zawartość kaweoliny oraz zróżnicowanie pod względem budowy wgłębień sprawia, że występują one tylko w określonych rodzajach komórek (komórkach nabłonkowych, śródbłonku, adipocytach, fibroblastach i pneumocytach typu I), podczas gdy tratwy lipidowe sa obecne we wszystkich tkankach (ZuWAŁA-JAGIEŁŁO 2004). Ze względu na wysokie zróżnicowanie fenotypowe kaweoli, sa one strukturami wciąz intensywnie badanymi. W ostatnich latach potwierdzono m.in. obecność CAV-1 w neuronach, gdzie moga wpływać na podział bądź łączenie kompleksów sygnalizacyjnych oraz inne istotne procesy zachodzące w układzie nerwowym (SEBASTIAO i współaut., 2012).

\section{INTERAKCJE CHOLESTEROLU Z BIAŁKAMI BŁONOWYMI}

Wyniki licznych badań molekularnych jednoznacznie wskazuja na regulacyjna rolę lipidów, w tym cholesterolu, w stosunku do białek obecnych w błonie komórkowej. W warunkach fizjologicznych cząsteczki cholesterolu moga modulować funkcje m.in. receptorów $z$ pętlą cysteinowa, receptorów zwiazanych $z$ białkiem $\mathrm{G}$, wewnątrzprostowniczych kanałów potasowych (KIR), kanałów jonowych (głównie wapniowych), akwaporyn czy białek transportowych (np. ATPaz typu P) (GROUlefF i współaut. 2015, SENGUPTA i CHATTOPADHYAY 2015). Analizy krystalograficzne pozwoliły określić miejsca wiazania cholesterolu do receptora serotoninowego typu 1A (SENGUPTA i CHATTOPADHYAY 2015) i kanału KIR 2.1 (GROULEFF i współaut. 2015), co świadczy o obecności bezpośrednich interakcji między lipidami i niektórymi białkami błonowymi. Co więcej, cholesterol może regulować ich funkcje także w sposób pośredni, zmieniając właściwości fizyko-chemiczne danego fragmentu błony (PAILA i CHATTOPADHYAY 2010).

Interakcje cząsteczek cholesterolu $z$ białkami błonowymi moga mieć również znaczenie $w$ rozwoju $i$ progresji wielu stanów chorobowych. W przypadku komórek raka prostaty, zwiększona ilość cholesterolu (zwłaszcza w tratwach lipidowych) prowadzi do wzmożonej aktywacji szlaków sygnalizacyjnych inicjowanych przez receptor dla epidermalnego czynnika wzrostu (ang. epidermal growth factor receptor, EGFR), a angażujacych kinaze Akt1. Ponadto, w bogatych w cholesterol fragmentach błon zidentyfikowano funkcjonalne formy receptorów jacdrowych: estrogenowego, androgenowego i receptora dla witaminy $D$. Zwiazana $z$ tym nadmierna aktywność wymienionych białek receptorowych może, jak wykazano, przyczyniać się do rozwoju choroby nowotworowej (FREEMAN i współaut. 2007).

\section{STEROIDOGENEZA}

W warunkach fizjologicznych cholesterol, oprócz funkcji strukturalnych w komórce, stanowi także substrat $\mathrm{w}$ procesie steroidogenezy. Synteza hormonów steroidowych przebiega wieloetapowo i wymaga obecności szeregu enzymów, przekształcających metabolity pośrednie do końcowych produktów, jakimi sa aldosteron i kortyzol w korze nadnerczy oraz estrogeny $\mathrm{i}$ testosteron w jajnikach i jądrach (ZAWIŚLAK i współaut. 2010, Miller i AUCHUS 2011). Wspomniane hormony moga być również syntetyzowane w łożysku, mózgu, skórze i tkance tłuszczowej, a razem umożliwiaja utrzymanie homeostazy nie tylko w okresie postnatalnym, ale także w trakcie rozwoju płodowego (GoźDZIKIEWICZ i GNIOT-SZULŻYCKA 2004).

Za podstawowe źródło cholesterolu w procesie steroidogenezy uznaje się wewnątrzkomórkowe krople lipidowe. Zakumulowane w nich estry cholesterolu sa dostarczane do mitochondriów (miejsce pierwszego etapu steroidogenezy) (MILLER 2013) dzięki obecności wimentyny, białka cytoszkieletu, wiążącego zarówno krople lipidowe (w formie kapsuły), jak i enzymy szklaku steroidogenezy. Potwierdzaja to obserwacje prowadzone $u$ myszy $z$ wyciszonym genem wimentyny, $u$ których zaobserwowano obniżona syntezę hormonu adrenokortykotropowego i progesteronu w jajnikach (KRAEMER i współaut. 2013).

\section{SYNTEZA WITAMINY $\mathrm{D}_{3}$}

Witamina $\mathrm{D}_{3}$, inaczej cholekalcyferol, w organizmie ludzkim pochodzi $z$ dwóch głównych źródeł: endogennego i egzogennego. Endogenna witamina $\mathrm{D}_{3}$ produkowana jest w skórze pod wpływem działania światła słonecznego, natomiast egzogenna jest dostarczana $z$ pożywieniem. W syntezie endogennej witaminy $\mathrm{D}_{3}$ ważna rolę odgrywa cholesterol, który pod wpływem promieniowania UVB przekształcany jest do 7-dehydrocholesterolu stanowiącego prekursor witaminy $\mathrm{D}_{3}$. W dalszym etapie 7-dehydrocholesterol ulega izomeryzacji do stabilnego cholekalcyferolu. Przemiana ta przebiega przy udziale reduktazy, a powstała witamina przedostaje się $z$ błon komórkowych, gdzie jest wytwarzana, do przestrzeni międzykomórkowych i w kompleksie $z$ białkami przechodzi do krwiobiegu. Następnie trafia do watroby, nerek i innych narządów, gdzie ulega hydroksylacji, 
czego konsekwencja jest powstanie aktywnego metabolitu - $1,25(\mathrm{OH})_{2} \mathrm{D}_{3}$. Działanie biologiczne witaminy $\mathrm{D}_{3}$ jest zależne od obecności receptora jądrowego VDR, należącego do rodziny receptorów steroidowych. Wraz z wiekiem zmniejsza się zdolność do produkcji witaminy $\mathrm{D}_{3}$, w związku ze spadkiem stężenia 7-dehydrocholesterolu, a niedobór cholekalcyferolu może prowadzić m.in. do krzywicy i osteoporozy, a także do schorzeń tkanki mięśniowej, chorób nowotworowych, chorób autoimmunologicznych, chorób układu krażenia czy depresji (PRZYBYŁO i współaut. 2016).

\section{CHOLESTEROL JAKO PREKURSOR KWASÓW ŻÓŁCIOWYCH}

Konwersja cholesterolu do kwasów żółciowych stanowi główny szlak katabolizmu tego związu. W procesie tym zaangażowanych jest 17 enzymów, głównie białka $z$ rodziny cytochromu P-450, a jego inicjacja, majaca miejsce w mitochondriach, może przebiegać droga klasyczna (hydroksylacja cholesterolu w pozycji 7a) lub alternatywna (hydroksylacja w pozycji 27). Opisano również dwie dodatkowe drogi, rozpoczynające się hydroksylacja w pozycji 24 i 25, ale ich znaczenie ilościowe jest niewielkie. Proces hydroksylacji zachodzi głównie w wątrobie, ale też w innych tkankach (mózg, skóra, nerki, jelito, prostata), a jego efektem jest powstanie produktów rozpuszczalnych w wodzie. W przypadku tkanek innych niż watroba, proces ten nie jest podstawa do syntezy kwasów żółciowych, stanowiąc sposób regulacji poziomu cholesterolu w komórkach. Produkty hydroksylacji powstajace poza watroba sa do niej transportowane wraz $z$ krwia i tam następuje ich dalsze przekształcenie do kwasów żółciowych. W watrobie dochodzi najpierw do szeregu reakcji, skutkujacych modyfikacjami w obrębie pierścieni aromatycznych hydroksylowanych pochodnych cholesterolu. Nastepnie powstałe pochodne ulegaja utlenieniu i dochodzi do skrócenia łańcucha bocznego, a proces ten ma miejsce w peroksysomach. Ostatnim etapem jest koniugacja powstałych tioestrów kwasu żółciowego-CoA $z$ czassteczkami tauryny lub glicyny, co zależne jest od stężenia tych aminokwasów w komórce. Przyłaczenie konkretnego aminokwasu nie zmienia właściwości emulgujących kwasów żółciowych (HEBANOWSKA 2010).

Kwasy żółciowe sa lepiej rozpuszczalne w wodzie niż wolny cholesterol i łatwiejsze do usunięcia $z$ organizmu. Wraz $z$ żółcia przechodzą do dwunastnicy. Obecne w żółci sole kwasów żółciowych, dzięki właściwościom zbliżonym do detergentów, uczest- nicza w trawieniu i wchłanianiu lipidów w jelicie cienkim. 95\% puli kwasów żółciowych jest następnie wtórnie wchłaniane w jelicie $\mathrm{i}$ transportowane do wątroby (krażenie wątrobowo-jelitowe). W skład żółci, poza kwasami żółciowymi, wchodzi też cholesterol, który obecny w niej w zbyt wysokim stężeniu ulega wytracaniu, powodując kamicę pęcherzyka żółciowego. Co istotne, kwasy żółciowe stanowią ligandy dla czynników transkrypcyjnych regulujacych ekspresje genów zaangażowanych w ich metabolizm (HEBANOWSKA 2010).

\section{CHOLESTEROL W ROZWOJU EMBRIONALNYM}

Rozwijajacy się płód, choć podejmuje syntezę cholesterolu, to jednak w pierwszych tygodniach ciaży wykorzystuje głównie cholesterol matczyny. Co więcej, nawet po porodzie, ok. 40-50\% cholesterolu we krwi noworodka pochodzi $z$ organizmu matki (BAARDMAN i współaut. 2013). Jego transport przez błony pęcherzyka żółtkowego, a później łożyska warunkuje prawidłowy rozwój zarodka i wykształcenie większości organów. Na endodermie pęcherzyka obecne sa receptory dla lipoprotein, m.in. receptory zmiatacze B1 (ang. scavenger receptor class B type 1), receptory dla kompleksu witamina $B_{12}$-czynnik Castle'a (kubilina), białko zwiazane $z$ receptorem dla LDL 2 (megalina lub LRP 2; ang. low-density lipoprotein receptor-related protein 2) oraz znaczne ilości receptora dla LDL (ang. low-density lipoprotein receptor, LDLR). W następnym etapie rozwoju embrionalnego pęcherzyk żółtkowy uwalnia do krążenia płodowego cholesterol $\mathrm{w}$ połaczeniu $\mathrm{Z}$ apolipoproteinami (ApoA1, ApoE i ApoB) zawartymi we frakcjach HDL, LDL lub VLDL (BAARDMAN i współaut. 2013).

Pobrane przez zarodek czasteczki cholesterolu uczestnicza w kluczowych dla rozwoju embrionalnego szlakach sygnalizacyjnych - reguluja funkcje białek sonic hedgehog (SHH). Białka te warunkuja przeżycie i migrację komórek grzebieni nerwowych oraz ważnych jadrowych receptorów, takich jak czynnik transkrypcyjny dla a-fetoproteiny, który poprzez wiąanie się $z$ sekwencjami GATA na nici DNA, umożliwia transkrypcję licznych genów zaangażowanych w rozwój najważniejszych organów (BAARDMAN i współaut. 2013). Genetycznie uwarunkowane zaburzenia gospodarki cholesterolu i wynikajace $z$ nich nieprawidłowości w przebiegu wybranych szlaków sygnalizacyjnych sa przyczyna wad rozwojowych. Sa one charakterystyczne m.in. dla pacjentów $Z$ syndromem Smith-Lemli-Opitz (ang. Smith-Lemli-Opitz syndrome, SLOS), u których obser- 
wuje się liczne wady wrodzone, głównie w obrębie układu nerwowego, oraz w schorzeniach, takich jak desmosteroloza i latosteroloza, zwiazanych $z$ akumulacją prekursorów cholesterolu (COOPER i współaut. 2003). Badania prowadzone $\mathrm{w}$ warunkach in vitro, na hodowlach komórkowych, $z$ użyciem blokujacych synteze cholesterolu cyklodekstryn pokazały, że we wszystkich trzech przypadkach niedobór cholesterolu obniża aktywność białka Smoothened (Smo), kluczowego elementu szlaku SHH (COOPER i współaut. 2003). Akumulacja toksycznych prekursorów cholesterolu i towarzyszace jej zaburzenia sygnalizacji $\mathrm{SHH}$ odpowiadaja również za część wad wrodzonych u pacjentów $z$ syndromem Conradiego-Hünermanna-Happlea (CHHS) i zespołem CHILD (ang. congenital hemi dysplasia with ichthyosiform erythroderma and limb defects). W przypadku CHHS mutacja w genie kodujacym izomerazę- $\Delta 8 \Delta 7$-hydroksysteroidową prowadzi do nagromadzenia 8-cholestenolu i 8-dehydrocholesterolu, a do jej fenotypowych manifestacji zalicza się ichtiozę (obecność na skórze struktur przypominajacych łuski), zaćmę i punktowa chondrodysplazję (nadmierny rozrost i wapnienie chrząstki) w nasadach kości długich (CAÑUETO i współaut. 2014). Podobne objawy obserwuje się także w przypadku zespołu CHILD, w którym, w wyniku mutacji w genie NSDHL, dochodzi do utraty funkcji dehydrogenazy $3 \beta$-hydroksysterolu (SEEGER i PALLER 2014).

\section{CHOLESTEROL A PATOGENEZA CHORÓB}

\section{CHOROBY NEURODEGENERACYJNE}

W mózgu skumulowane jest około 23\% z występujacej w organizmie człowieka puli cholesterolu, a jego obecność warunkuje prawidłowe funkcjonowanie komórek nerwowych, zarówno w wieku rozwojowym, jak i w dorosłym życiu. Duża ilość cholesterolu znajduje się także w wytwarzanych przez oligodendrocyty osłonkach mielinowych, otaczających aksony. Bogate w cholesterol sa również neurony i astrocyty, gdzie pełni on ważne funkcje w utrzymaniu złożoności morfologicznej i przewodnictwa synaptycznego (MARTIN i współaut. 2014).

Cała pula cholesterolu w ośrodkowym układzie nerwowym (OUN) produkowana jest w mózgu, gdyż ze względu na występowanie bariery krew-mózg żadna $\mathrm{z}$ komórek OUN nie pobiera cholesterolu $z$ krwi obwodowej. Stąd też, w przypadku nienaruszonej bariery krew-mózg, neurony i inne komórki OUN zasadniczo nie ulegają wpływowi zmian poziomu cholesterolu we krwi. Z drugiej jednak strony, cholesterol jest stale usuwany $z$ OUN dzięki specyficznej dla neuronów oksydazie Cyp46A1 cytochromu P450. Enzym ten katalizuje przyłaczenie do cholesterolu grupy -OH i powstanie 24S-hydroksycholesterolu, który, przekroczywszy barierę krew-mózg, jest transportowany $z$ krwia i zostaje zmetabolizowany w watrobie (MARTIN i współaut. 2014). Istotne znaczenie cholesterolu dla prawidłowego funkcjonowania tkanki mózgowej potwierdza występowanie szeregu wspomnianych już dziedzicznych chorób, powodowanych mutacjami w genach zwiazanych $z$ jego metabolizmem. Niestety we wszystkich tych chorobach bariera krew-mózg uniemożliwia regulacje poziomu cholesterolu w mózgu na drodze suplementacji. Przykładami takich schorzeń sa m.in. syndrom Smith-Lemli-Opitza, choroba Niemanna-Picka typu C, czy zespół Retta.

Syndrom Smith-Lemli-Opitza (SLOS) to choroba o podłożu autosomalnym recesywnym, zwiazana $z$ mutacja $w$ genie kodujacym reduktaze 7-dehydrocholesterolu. Skutkuje ona zaburzeniami w metabolizmie cholesterolu (wzrost poziomu 7-dehydrocholesterolu, który jest prekursorem cholesterolu) i licznymi zaburzeniami w prawidłowym funkcjonowaniu układu nerwowego. Objawami towarzyszacymi SLOS są: zachowania autystyczne, upośledzenie umysłowe, problemy ze snem czy zaburzenia behawioralne. Większość pacjentów ze SLOS cechuje także opóźnione dojrzewanie mowy i motoryki. Uznaje się, że symptomy te moga być spowodowane zredukowanym poziomem cholesterolu w komórkach nerwowych, gdyż w mózgu pacjentów ze SLOS znajduje się zaledwie $2 \%$ ilości cholesterolu występującej u ludzi zdrowych (THURM i współaut. 2016). Badania wykazały, że pacjenci o łagodniejszych objawach charakteryzują się normalnym stężeniem cholesterolu w błonach komórek nerwowych, co prawdopodobnie jest spowodowane jego miejscowa synteza. Jednocześnie wydaje się, że symptomy chorobowe moga być również skutkiem akumulacji 7,8-dehydrodesmosterolu lub jego utlenionych metabolitów (MARTIN i współaut. 2014).

Innym przykładem dziedzicznego schorzenia, charakteryzującego się zaburzeniami w metabolizmie cholesterolu, jest choroba Niemanna-Picka typu C (NPC). Przyczyna tej choroby sa mutacje w genie NPC1 lub NPC2, przy czym w około 95\% przypadków mutacja dotyczy genu NPC1. Wspomniane geny koduja białka transportujace cholesterol (NPC1, NPC2), co w przypadku wystąpienia mutacji, prowadzi do akumulacji niezestryfikowanego cholesterolu i innych lipidów w późnych endosomach i lizosomach. Zaburzenia dotycza zarówno transportu wewnątrzkomórkowego 
wybranych cząsteczek, jak i obserwuje się liczne zmiany morfologiczne w peccherzykach synaptycznych. Mutacje w genie NPC1 lub NPC2 prowadza do niemal identycznych objawów klinicznych. Symptomy NPC zwykle pojawiają się już we wczesnym dzieciństwie, lecz wiek zachorowania i szybkość progresji choroby moga być zróżnicowane. Zarówno u myszy, jak i u człowieka najpoważniejsze konsekwencje zwiazane $z$ występowaniem NPC wynikaja ze zmian neurodegeneracyjnych, dotyczących głównie komórek Purkinjego w móżdżku, co skutkuje zaburzeniami zdolności motorycznych. Neurodegeneracja obejmuje też inne regiony mózgu, objawiając się pęcznieniem neuronów czy nieprawidłowym formowaniem się dendrytów, co ma niezwykle istotny wpływ na funkcjonowanie tkanki mózgowej. Wszystkie te zaburzenia prowadza do zmniejszenia tempa przyrostu masy ciała, ograniczenia zdolności poznawczych oraz skutkuja przedwczesna śmiercia. Co charakterystyczne, NPC zwykle towarzyszy ostra niewydolność wątroby. Większość obwodowego cholesterolu (około 80\%), w postaci LDL, jest endocytowana przez hepatocyty, stąd też akumulacja cholesterolu jest bardziej znaczacca w lizosomach watroby niż innych tkanek (VANCE i KARTEN 2014).

Kolejna choroba dziedziczna zwiazana $Z$ cholesterolem jest syndrom Retta. Schorzenie to dotyka wyłącznie kobiety, a częstość jego występowania to 1/10000-15000 urodzeń. Chore niemowlęta płci żeńskiej rozwijają się normalnie przez pierwsze 6-18 miesięcy życia, po czym dochodzi do stopniowej utraty zdolności swobodnego mówienia i wykonywania czynności manualnych. Większość pacjentów $z$ syndromem Retta to heterozygoty $z$ mutacja genu Mecp2 sprzężonego $\mathrm{z}$ chromosomem X. Gen ten koduje białko regulujące ekspresję kilku genów w komórkach nerwowych poprzez wiazanie metylowanych fragmentów DNA (GUY i wspólaut. 2001). Dotychczas syndrom Retta nie był kojarzony $z$ wadliwym metabolizmem cholesterolu, jednak wyniki ostatnich badań sugeruja, że białkowy produkt genu Mecp2 może być zaangażowany w kontrolę metabolizmu cholesterolu na poziomie transkrypcji. Zaobserwowano, że mutacja supresorowa w genie Sqle, kodujacym epoksydazę skwalenu (kluczowy enzym w syntezie cholesterolu), wystarczała by przywrócić prawidłowe funkcjonowanie i długowieczność u myszy $z$ nokautem genu Mecp2. Pomiary poziomu syntezy cholesterolu de novo potwierdziły postępująca wraz $z$ wiekiem hipercholesterolemię $\mathrm{u}$ myszy $\mathrm{z}$ nokautem, podczas gdy u dorosłych myszy $z$ mutacja supresorowa poziom cholesterolu oscylował w granicach normy (MARTIN i współaut. 2014).
Wśród schorzeń majacych jednoznaczne powiazanie $z$ cholesterolem wyróżnia się także niedziedziczne choroby neurodegeneracyjne, a jedna $z$ najszerzej badanych jest choroba Alzheimera. Jak pokazano, cholesterol odgrywa istotna rolę w przekształcaniu białkowego prekursora beta amyloidu (ang. amyloid precursor protein, APP) do czasteczki toksycznego beta amyloidu $(A \beta)$, bezpośrednio przyczyniającego się do progresji AD (WolozIN 2004). Beta amyloid jest 39-42 aminokwasowym peptydem, będacym naturalnym produktem rozpadu dużo większej cząsteczki APP. A $\beta$ występuje w organizmie człowieka w dwóch formach, a istotniejsza dla patogenezy AD cząsteczka jest forma $\mathrm{A} \beta 42$. Mechanizm, poprzez który cholesterol wpływa na metabolizm beta amyloidu, nie jest dokładnie poznany, jednak wykazano, że cholesterol i gangliozyd GM1, obecne w tratwach lipidowych, maja duże powinowactwo do $A \beta 42$ i moga wpływać na przyjmowanie przez $A \beta$ nieprawidłowej konformacji oraz indukować proces jego polimeryzacji. W warunkach fizjologicznych neurony wykorzystuja cholesterol produkowany przez astrocyty, jednak w przypadku hipercholesterolemii zmienia się przepuszczalność bariery krew-mózg, co umożliwia przenikanie $z$ krą̇̇nia dodatkowej puli wielonienasyconych kwasów tłuszczowych i cholesterolu (w postaci LDL i VLDL). Prowadzi to do zaburzeń w metabolizmie komórek nerwowych. Cholesterol, jego estry i utlenione formy (głównie 27-hydroksysterol) reguluja poziom $A \beta$ w mózgu i stymuluja jego produkcję, ale ich nadmiar (związany ze zwiększoną przepuszczalnościa bariery krew-mózg) może przyczyniać się do agregacji A $\beta$ i rozwoju AD (MAULIK i współaut. 2013, SUn i współaut. 2015, XUE-SHAN i współaut. 2016).

Cholesterol może przyczyniać się również do rozwoju choroby Parkinsona (ang. Parkinson's disease, PD). Jest to choroba postępujaca, a liczbę chorych na świecie szacuje się na ponad 5 milionów. Objawia się ona utrata neuronów dopaminergicznych w istocie czarnej oraz powstawaniem ciałek Lewyego, bogatych w a-synukleinę. Liczne badania osoczowego profilu lipidowego $u$ pacjentów cierpiacych na PD sugeruja, że cholesterol jest zaangażowany w powstawanie i progresję tej choroby. U osób chorych na PD zaobserwowano podwyższony poziom oksysteroli (w tym cholesterolu i jego produktów pośrednich), który przyczynia się do agregacji a-synukleiny w ciałkach Lewy'ego. Udowodniono również, że 24-hydroksysterol, jak i 27-hydroksysterol podnosza poziom ekspresji a-synukleiny, dopaminy i noradrenaliny oraz wywołuja śmierć komórek nerwowych (DORIA i współaut. 2016). 
Poza udziałem w patogenezie chorób, cholesterol jest jednocześnie zaangażowany w szereg działających w OUN mechanizmów neuroprotekcyjnych, w których istotna rolę odgrywaja hormony steroidowe. Komórki nerwowe wykazuja ekspresję enzymów niezbędnych do syntezy i metabolizmu steroidów, a produkowane w OUN estrogeny wpływaja na wzrost plastyczności synaptycznej, ograniczaja formowanie A $\beta$ z APP, przeciwdziałaja ekspresji czynników proapoptotycznych i wykazuja właściwości antyoksydacyjne. Zdolności neuroprotekcyjne sa zwiazane również $z$ działaniem androgenów, które stymulują różnicowanie się neuronów oraz ich pobudliwość, a także progesteronem, który reguluje proces mielinizacji i zapobiega apoptozie indukowanej neurotoksynami. Neuroprotekcyjną rolę hormonów steroidowych potwierdzaja wyniki badań prowadzonych w grupach pacjentek stosujących hormonalną terapię zastępcza. Metaanaliza badań dotyczacych korelacji pomiędzy hormonalna terapia zastępcza a zachorowalnościa na AD pokazała, że podawanie estrogenu istotnie zmniejszało ryzyko zachorowania na AD. Molekularny mechanizmy neuroprotekcyjnego działania estrogenu nie jest do końca poznany, ale dotychczas prowadzone badania sugeruja, że zaangażowane jest $\mathrm{w}$ tu białko seladyna-1 (produkt genu DHCR24, enzym katalizujaccy konwersję desmosterolu do cholesterolu). Obniżona ekspresja tego białka w neuronach jest charakterystyczna dla AD. Jak wykazano na modelu ludzkich prekursorowych komórek neuronalnych (ang. fetal neuroepithelial cells, FNC), działanie estrogenu i selektywnych modulatorów receptora estrogenowego (ang. selective estrogen receptor modulators, SERMS), tj. tamoksyfenu i raloksyfenu, niwelowało toksyczne efekty działania $\beta$-amyloidu i stresu oksydacyjnego. Jednocześnie w komórkach tych dochodziło do wzmożonej ekspresji genu DHCR24. Co interesujace, w komórkach FNC $z$ wyciszonym genem DHCR24, wspomniane protekcyjne efekty działania estrogenu i SERMS nie były obserwowane. Neuroprotekcyjne działanie estrogenów powiazano zatem $z$ antyoksydacyjna aktywnościa seladyny 1, dajaca komórkom odporność na działanie $\beta$-amyloidu (DRZEWIŃSKA i współaut. 2009, PERI 2016).

\section{CHOROBY ZWIAZZANE Z UKŁADEM KRĄŻENIA}

Choroby zwiazane $z$ układem krażenia (ang. cardiovascular diseases, CVDs) sa najpowszechniej występująca grupa schorzeń. Tylko w 2012 r. CVDs były przyczyna śmierci 17,5 miliona ludzi, co stanowiło aż $31 \%$ wszystkich zgonów. Badania wykazały, że 7,4 miliona zgonów spowodowanych było chorobą wieńcową serca, natomiast 6,7 miliona ludzi zmarło w wyniku zawału mięśnia sercowego. W większości przypadków można zminimalizować ryzyko wystapienia CVD lub załagodzić objawy poprzez kontrolę szeregu czynników ryzyka, którymi sa głównie: wysokie ciśnienie krwi, palenie papierosów, cukrzyca czy otyłość. Istotnym czynnikiem, przyczyniającym się do około 1/3 zgonów spowodowanych przez wszystkie CVDs, jest podwyższony poziom cholesterolu we krwi. Jego regularna kontrola pozwala na oszacowanie indywidualnego ryzyka wystapienia CVDs, może także pozwolić odpowiednio wcześnie zareagować na jego podwyższony poziom poprzez rozpoczęcie odpowiedniej terapii $z$ użyciem statyn, czy innych leków regulujacych poziom lipidów w organizmie (PETERs i współaut. 2016).

Niezwykle powszechna choroba zwiąaną $z$ układem krążenia jest miażdżyca. Jej postęp jest ściśle związany $z$ nieprawidłowościami w metabolizmie lipidów, objawiającymi się wzrostem poziomu całkowitego cholesterolu oraz frakcji LDL, a także spadkiem zawartości frakcji HDL w osoczu (HoNDA i współaut., 2016). Zmiany miażdżycowe tętnic można zaobserwować już u dzieci, a powyżej 15 roku życia sa one wykrywane niemalże $u$ wszystkich. Zmiany te moga $z$ czasem doprowadzić do wystapienia szeregu schorzeń układu krążenia, a w konsekwencji do śmierci. Niewielkie zmiany miażdżycowe w większości przypadków nie powodują objawów klinicznych, dopiero duże blaszki (zajmujace $70-80 \%$ światła tętnicy), bogate w lipidy, ulegajace martwicy i wapnieniu oraz pokryte warstwa włóknika, zmniejszaja dopływ krwi do serca, wywołujac groźne powikłania (np. dusznicę bolesna). W procesie formowania się blaszek może dochodzić także do ich gwałtownego pękania i najczęściej ma to miejsce, gdy obejmuja one mniej niż $50 \%$ światła naczynia. Co istotne, częściej dochodzi do pękania blaszek miażdżycowych w tętnicach wieńcowych niż w naczyniach obwodowych, co wynika $z$ mniej stabilnej struktury powstajacych tam blaszek. Objawami towarzyszacymi pęknięciu blaszki sa m.in. ostre zespoły wieńcowe czy udar mózgu (KUCHARSKA 2014).

Kluczowe znaczenie dla przebiegu procesu powstawania blaszek miażdżycowych maja zaburzenia funkcjonowania śródbłon$\mathrm{ka}$, zaburzenia metabolizmu lipidów oraz szereg czynników immunologicznych i genetycznych. Główną rolę w powstawaniu i rozwoju miażdżycy odgrywa miejscowy proces zapalny, obejmujacy ścianę tętnicy (KUCHARSKA 2014). W wyniku aktywacji i dysfunkcji śródbłonka naczyń, dochodzi wówczas do zwiększonej adhezji leukocytów i płytek 
krwi do śródbłonka, a jednocześnie wzrasta przepuszczalność naczyń dla LDL. Cząsteczki cholesterolu $z$ LDL ulegaja utlenieniu do oksysteroli i sa pochłaniane przez makrofagi, które w dalszej kolejności przekształcaja się w tak zwane komórki piankowate. W konsekwencji, w ścianie tętnicy tworzy się bogaty w lipidy rdzeń blaszki miażdżycowej, powstajacy ze skumulowanych pozakomórkowych złogów cholesterolu, a błona wewnętrzna naczynia staje się coraz grubsza. Rdzeń ten może stanowić nawet do $60 \%$ objętości blaszki, a w jego strukturze wyróżnia się warstwy: komórek piankowatych, komórek martwiczych i skrystalizowanego cholesterolu, który może podlegać zwapnieniu. Następnie, $z$ pasm tłuszczowych rozwijaja się dojrzałe płytki miażdżycowe otoczone macierza kolagenowa i komórkami mięśni gładkich, które od strony światła naczynia tworza strukturę określana jako czapeczka włóknista. Stała sekrecja proteaz i cytokin przez komórki układu odpornościowego prowadzi do uszkodzenia łacznotkankowej otoczki blaszek i w konsekwencji do jej rozpadu. Jak wykazano, obecność dużego rdzenia lipidowego zwiększa ryzyko pękania blaszek miażdżycowych. Pęknięcie blaszki powoduje uwolnienie zawartego w niej cholesterolu, który musi na zasadzie transportu odwrotnego, w postaci HDL, trafić do wątroby, gdzie zostanie zmagazynowany, przetworzony lub usunięty $z$ źółcią (PASIERSKI i GACIONG 2004, RYSTWEJ-NIEDŹWIEDZKA i współaut. 2010).

Frakcja HDL, w odróżnieniu od LDL, uważana jest za frakcję antyaterogenna (o działaniu przeciwmiażdżycowym). Poziom cholesterolu w formie HDL jest odwrotnie proporcjonalny do częstości występowania CVDs. Jednak terapie polegajace na podwyższaniu poziomu HDL, np. przez podawanie niacyny przy jednoczesnym stosowaniu statyn, nie dały oczekiwanego efektu w postaci spadku liczby zachorowań na CVDs. Co więcej, okazało się, że stosowanie Torcerapibu, inhibitora białka przenoszacego estry cholesterolu (ang. cholesteryl ester transfer protein, CETP), choć podnosiło poziom cholesterolu w HDL o około $60 \%$, to jednocześnie skutkowało zwiększona śmiertelnościa pacjentów i częściej występującymi w tej grupie CVDs (BHATT i ROHATGI, 2016).

Innym schorzeniem układu krażenia, zwiazanym $z$ metabolizmem cholesterolu, jest dziedziczna hipercholesterolemia (ang. familial hipercholesterolemia, FH). Jest to choroba autosomalna dominujaca, występujaca w populacjach większości państw europejskich. Osoby cierpiace na $\mathrm{FH}$ charakteryzuja sie podwyższonym poziomem frakcji LDL cholesterolu, co prowadzi do szybkiego rozwoju zmian miażdżycowych i innych chorób zwiazanych $z$ układem krażenia. Pacjenci cierpiacy na $\mathrm{FH}$ wymagaja intensywnego leczenia, często $\mathrm{z}$ zastosowaniem szeregu środków obniżajacych poziom obwodowego LDL. Choroba ta może być spowodowana mutacjami w obrębie trzech genów: w genie kodujacym receptor LDLR, genie kodujacym apolipoproteinę B oraz w genie kodujacym konwertaze proproteiny subtylisina/keksyna typu 9 (ang. pro protein convertase subtilisin/kexin type 9, PCSK9). Mutacje te prowadzą do zaburzeń w usuwaniu frakcji LDL $z$ krwi obwodowej, co ma zwiazek $z$ funkcjami pełnionymi przez produkty wymienionych genów. Receptory LDL, obecne głównie w błonach komórkowych hepatocytów, odpowiedzialne sa za wyłapywanie frakcji LDL $z$ osocza. Apolipoproteina $B$ jest białkiem umożliwiajacym wiazanie LDL do LDLR, natomiast PCSK9 jest odpowiedzialna za degradację receptorów LDL. Mutacja genu dla PCSK9 i nadprodukcja tego białka skutkuje spadkiem liczby LDLR w komórkach watroby i w konsekwencji hiperlipidemia. U heterozygot ( $\mathrm{z}$ pojedyncza kopia wadliwego genu) prowadzi to do akumulacji LDL w osoczu, a homozygoty (posiadajace 2 kopie zmutowanego genu) charakteryzuja się minimalnym poziomem usuwania LDL $Z$ osocza (TURGEON i współaut. 2016).

\section{CHOROBY NEREK}

Powszechnym schorzeniem równiė̇ powiązanym $z$ metabolizmem cholesterolu jest przewlekła choroba nerek (ang. chronic kidney disease, CKD), na która cierpi średnio 1 na 10 dorosłych osób. W jej przebiegu obserwuje się postępujaca dysfunkcję nerek, jednak brak jest charakterystycznych objawów umożliwiających jednoznaczna diagnozę. Bardzo często towarzyszą jej także schorzenia układu krążenia, co komplikuje obraz choroby i utrudnia rozpoznanie. CKD może prowadzić do powstania schyłkowej niewydolności nerek (ang. end-stage renal disease, ESRD) i śmierci. Pomimo tego, tylko niewielka liczba pacjentów $z$ CKD zapada na ESRD, gdyż większość $z$ nich umiera wcześniej w związku $z$ powikłaniami ze strony układu krażenia (HAYNES i współaut. 2014, GARGIULO i współaut. 2016). U osób cierpiących na CKD obserwuje się nieprawidłowości w metabolizmie lipidów i zaburzenia $w$ ich profilu osoczowym, zmieniajace się wraz $z$ progresją choroby. U pacjentów $\mathrm{w}$ poczatkowych fazach choroby zwykle obserwuje się hipercholesterolemię oraz podwyższony poziom LDL. Mimo to, $u$ pacjentów $z$ ESRD poddawanych hemodializie, całkowity cholesterol i jego frakcja LDL sa zwykle na normalnym poziomie lub sa nieznacznie zredukowane (VAZIRI i NORRIS 2011). 
W przebiegu i progresji CKD swój udział mają również VLDL, IDL, HDL oraz chylomikrony. VLDL i chylomikrony stanowia magazyn tłuszczy, które dostarczane sa do mięśni jako źródło energii i do adipocytów w celu ich zmagazynowania. W procesie tym udział bierze, obecna w naczyniach krwionośnych, lipaza lipoproteinowa. W efekcie jej działania uwolnionych zostaje około $70 \%$ kwasów tłuszczowych zmagazynowanych w formie trójglicerydów w VLDL i chylomikronach, a VLDL przekształcaja się w IDL. Proces usuwania IDL $z$ osocza zachodzi po ich wcześniejszej konwersji do LDL. Konwersja ta wymaga wzbogacenia IDL cholesterolem i usunięcia obecnych w obrębie tej lipoproteiny trójglicerydów. Proces ten odbywa się przy udziale CETP, który umożliwia wymianę trójglicerydów $z$ IDL na estry cholesterolu pochodzace $z$ czasteczek HDL. Powstałe w ten sposób, bogate $\mathrm{w}$ cholesterol a ubogie w trójglicerydy, cząsteczki LDL moga być $z$ łatwościa wiazane i usuwane $z$ osocza przez receptory dla tych lipoprotein, wystepujace na komórkach wattroby. U osób $z$ ESRD obserwuje się podwyższony poziom frakcji VLDL i trójglicerydów w osoczu, co jest zwiazane $z$ zaburzeniami w procesie usuwania cholesterolu $z$ VLDL i chylomikronów. Zaburzenia te $\mathrm{w}$ przebiegu CKD wynikaja $z$ obniżonej ekspresji receptora dla VLDL oraz niższego poziomu ekspresji i aktywności lipazy lipoproteinowej. U osób $z$ CKD stwierdzono ponadto obniżona ekspresję i aktywność lipazy watrobowej. Skutkuje to akumulacją IDL, wzbogaceniem trójglicerydami cząsteczek LDL i HDL oraz hipertrójglicerydemia, jaka obserwowana jest u chorych na CKD (VAZIRI i NORRIS 2011).

Charakterystyczny dla chorych na CVDs jest także podwyższony stosunek ApoC-III (inhibitor lipazy lipoproteinowej) do ApoC-II (aktywator lipazy lipoproteinowej) w osoczu oraz w VLDL i chylomikronach, co znacznie obniża ich zdolność do aktywacji lipazy. Ponadto, redukcja poziomu ApoE w VLDL i chylomikronach osłabia ich adhezję do śródbłonka naczyń włosowatych, co skutkuje ograniczeniem ich interakcji z lipaza lipoproteinowa i receptorami w tkankach (VAzIRI i NORRIS 2011).

U osób cierpiących na CKD obserwuje się też redukcję osoczowej frakcji HDL, wtórną w stosunku do występującego wcześniej spadku poziomu białek: ApoA-I i ApoA-II. ApoA-I jest kluczowym kofaktorem enzy$\mathrm{mu}$, acylotransferazy lecytyno-cholesterolowej (ang. lecithin-cholesterol acylotransferase, LCAT), która jest odpowiedzialna za wychwyt estrów cholesterolu. Zaburzenia funkcji Apo-I i LCAT skutkuja zmianami w transporcie cholesterolu i zmniejszeniem ilości HDL, co w efekcie może prowadzić do powstawania blaszek miażdżycowych w naczyniach krwionośnych nerek (KOWALSKI i współaut. 2015). Rozwój miażdżycy powodują również towarzyszace CKD: stres oksydacyjny i stan zapalny (VAZIRI i NORRIS 2011, KON i współaut. 2015). Jak wykazano, oksydacja HDL u chorych na ESRD, powodowała zaburzenia $\mathrm{w}$ realizowanym przez nie odwrotnym transporcie cholesterolu, a tym samym przyczyniała się do pogłębiania problemów kardiologicznych u tej grupy chorych (ANDERSON i współaut. 2016).

Dane kliniczne sugeruja, że choroby układu krążenia zwiazane $z$ miażdżyca pojawiają się znacznie częściej u osób cierpiących na CKD niż u osób nie dotkniętych ta choroba (MASSY i DE ZEEUW 2013), a szczególnie narażeni na wystapienie tych komplikacji sa pacjenci dializowani (KoN i współaut. 2015). Obserwacje kliniczne dotyczace pacjentów $z$ CKD przemawiaja za stosowaniem terapii statynami i obniżaniem poziomu cholesterolu, jako sposobem redukcji ryzyka wystapienia miażdżycy. Jednocześnie brak niezaprzeczalnych dowodów na pozytywny wpływ podobnych terapii na obniżenie ryzyka wystapienia chorób układu krążenia u pacjentów chorych na ESRD (MASSY i DE ZEEUW 2013).

\section{CHOROBY NOWOTWOROWE}

Komórki większości tkanek ludzkiego organizmu wykazująca zdolność zarówno do syntezy cholesterolu, jak i do absorpcji lipoprotein $z$ krwioobiegu. Ilość cholesterolu w błonach komórkowych jest regulowana m.in. na poziomie transkrypcji genów, podczas jego syntezy w siateczce śródplazmatycznej oraz w trakcie transferu $z$ lipoprotein. Badania pokazuja, że deregulacja tych procesów towarzyszy starzeniu się tkanek oraz progresji nowotworowej, przez co w obrębie guzów różnych typów nowotworów dochodzi do akumulacji cholesterolu. Dotyczy to wszystkich błon komórkowych, włącznie $z$ błonami mitochondrium (RIBAs i współaut. 2016). Jego zawartość jest zmieniona także w zdrowych tkankach bezpośrednio otaczajacych zmiany nowotworowe (DI VIzIO i współaut. 2008). Wykazano, że bogate w cholesterol tratwy lipidowe sa zaangażowane w procesy adhezji i migracji komórek nowotworowych. W warunkach in vitro obniżenie poziomu cholesterolu wpływało na zahamowanie migracji komórek poprzez blokowanie translokacji i reorganizacji w obrębie tratw lipidowych cząsteczek adhezji komórkowej, takich jak CD44 czy integryny. Jednocześnie, dezorganizacja tratw lipidowych umożliwiała dostęp enzymom proteolitycznym, jak ADAM10, do ich substratów np. CD44, co 
dodatkowo zaburzało oddziaływania międzykomórkowe i zależna od nich migrację komórkowa. Tratwom lipidowym i obecnemu w nich cholesterolowi przypisano rolę w regulacji m.in. inwazji komórek raka piersi. Obecność tratw lipidowych jest niezbędna dla procesów tworzenia przez komórki nowotworowe inwadipodiów, błonowych wypustek, których rola jest inicjacja degradacji macierzy pozakomórkowej, co stanowi ważny etap w procesie inwazji (MURAI 2012).

Wcześniejsze badania epidemiologiczne sugerowały brak związku między poziomem osoczowego cholesterolu a ryzykiem wystąpienia nowotworu. Obecnie uważa się, że istnieje pozytywna korelacja między długotrwała konsumpcja bogatych w cholesterol posiłków a wystapieniem nowotworu w określonych tkankach. Wysoki poziom cholesterolu często jest czynnikiem towarzyszacym otyłości, stąd pojawiła się sugestia istnienia korelacji pomiędzy otyłościa a rozwojem nowotworów. Zwiazek taki opisany został w przypadku raka piersi, gdzie otyłość i towarzyszacy jej wysoki poziom cholesterolu we krwi sprzyjały rozwojowi guzów nowotworowych. Wykorzystujac model mysi wykazano, iż wzrost poziomu egzogennego cholesterolu we krwi jest pozytywnie skorelowany $z$ wzrastajaca szybkościa rozwoju raka piersi. Jego obecność obniża latencję oraz przyspiesza tempo proliferacji komórek nowotworowych. Istotna rolę $\mathrm{w}$ rozwoju raka piersi przypisano także metabolitom cholesterolu - oksysterolom, a przede wszystkim 27-dehydroksycholesterolowi (27HC). Selektywnie wiążąc się $z$ receptorami estrogenowymi $27 \mathrm{HC}$ wywołuje wzmożona proliferację komórek oraz wzrost guzów nowotworowych. Co więcej, zasugerowano, że oddziaływanie $27 \mathrm{HC}$ $z$ watrobowym czynnikiem transkrypcyjnym (ang. liver $\mathrm{X}$ receptor, LXR) sprzyja tworzeniu przerzutów przez komórki raka piersi. Odbywa się to na drodze inicjowania przez kompleks 27HC-LXR przejścia epitelialno-mezenchmalnego komórek raka piersi, a to jest istotnym etapem $\mathrm{w}$ nabywaniu przez nie fenotypu złośliwego. Obniżanie poziomu cholesterolu może być zatem skuteczna metoda zapobiegania lub walki $z$ tym nowotworem (BAEK i NELSON 2016, MURAI 2015). Wzrost poziomu cholesterolu został powiazany także $z$ patogeneza nowotworu prostaty. Jak zaobserwowano, wprowadzenie komórek ludzkiego raka prostaty do organizmu myszy skutkowało wzrostem poziom cholesterolu we krwi oraz zwiększona jego zawartościa w tratwach lipidowych, co przyczyniało się do rozwoju nowotworu (DI VIZIO i współaut. 2008, Pelton i współaut. 2012). Cholesterol jest również istotnym czynnikiem ryzyka w przypadku nowotworu jelita grubego. Wy- stepowanie tego nowotworu zwiazane jest $\mathrm{Z}$ obecnościa szeregu mutacji, jakkolwiek istotne znaczenie dla jego rozwoju maja czynniki środowiskowe. Do najważniejszych zalicza się tłuszcze pobierane $z$ pożywieniem oraz wysoki poziom kwasów tłuszczowych i cholesterolu w osoczu. Jak pokazano poziom całkowitego cholesterolu, LDL oraz wysoka wartość stosunku LDL/HDL pozytywnie koreluja $z$ rozwojem raka jelita grubego, podczas gdy wysoki poziom HDL wiazany jest $z$ zahamowaniem jego wzrostu (YAN i współaut. 2016).

\section{PODSUMOWANIE}

Cholesterol to kluczowy komponent błon komórkowych oraz substrat w procesie steroidogenezy, a jego udział $w$ rozwoju embrionalnym i w fizjologii organizmu w okresie życia postnatalnego jest niepodważalny. Tytułowa "druga twarz" cholesterolu to jego, potwierdzony obserwacjami klinicznymi i wynikami badań molekularnych, udział w patogenezie wielu schorzeń, takich jak: miażdżyca, choroba Alzheimera, choroby nerek czy nowotwory. W stanach patologicznych dochodzi najczęściej do zaburzeń wchłaniania, transportu lub metabolizmu cholesterolu. Obserwacje te skłoniły do podjęcia prób wykorzystania procesów zwiazzanych $z$ obrotem cholesterolu w organizmie, jako celu terapeutycznego oraz włączenia lipidogramu do kanonu diagnostycznego wspomnianych schorzeń. W chorobach układu krażenia, od dłuższego już czasu, szeroko stosowane sa statyny, grupa leków regulujących poziomu cholesterolu. Ich działanie polega na inhibicji poczatkowych etapów syntezy cholesterolu w hepatocytach i zwiększaniu syntezy receptorów dla LDL, wskutek czego dochodzi do wzrostu poziomu HDL, a spadku LDL i trójglicerydów w osoczu (ELSHOURBAGY i współaut. 2014). Jednak ze względu na liczne skutki uboczne, a także zależność terapii od interakcji $z$ innymi lekami, jak $i$ indywidualnych predyspozycji chorego, pozytywny efekt działania statyn poddawany jest w wątpliwość i budzi liczne kontrowersje. Co więcej, w przypadku schorzeń neurodegeneracyjnych, jak choroba Alzheimera, skuteczność terapii $z$ zastosowaniem statyn jest ograniczona ze względu na obecność bariery krew-mózg, którą przekraczać moga tylko niewielkie molekuły, podczas gdy większość leków to duże czasteczki. Jakkolwiek wyniki badań sugeruja, że redukcja poziom cholesterolu, m.in. $z$ użyciem statyn, zapobiega rozwojowi choroby Alzheimera u osób zdrowych, a u osób już chorujacych spowalnia jej progresję (BUTTERFIELD i współaut. 2011). 
Prowadzone obecnie badania skupiaja się na stworzeniu skuteczniejszych i niosacych mniej skutków ubocznych leków, które pozwola regulować metabolizm cholesterolu w obrębie całego organizmu. Jedna $z$ takich innowacyjnych metod jest indukowanie ApoE. Przypuszcza się, że u homozygot pod względem allelu ApoE4 dochodzi do upośledzenia metabolizmu cholesterolu i lipidów w OUN, co sprzyja rozwojowi choroby Alzheimera. Indukcję ApoE4 można przeprowadzić z udziałem leku przeciwmiażdżycowego, probucolu, który podnosi ekspresje mRNA kodujacego ApoE w śledzionie. Badania pokazały, że lek ten skutecznie podnosił poziom ApoE w płynie mózgowo-rdzeniowym i jednocześnie obniżał poziom $\beta$-amyloidu (POIRIER i współaut. 2014). Opracowanie nowych leków regulujacych poziom cholesterolu pozwoliłoby bezpiecznie regulować jego poziom, a przez to wspomagać proces terapeutyczny, także w przypadku innych schorzeń, np. nowotworów.

Obiecującym kierunkiem badań jest wykorzystanie znaczacego udziału cholesterolu w konstytucji błon komórkowych oraz jego zdolność wiąania się do wielu białek błonowych, co stwarza możliwości wykorzystania go jako celu dla nowoopracowywanych strategii terapeutycznych. Syntetyczne lipoproteiny (HDL, LDL i VLDL) sa obecnie testowane jako donory leków, a ich wysoka biokompatybilność (lipofilna powierzchnia i obecność wiążących je receptorów we wszystkich tkankach) oraz znikoma immunogenność pozwalaja na przyswojenie optymalnej dawki leku bez strat czy niepożądanych efektów ubocznych, które towarzysza obecności wolnych cząsteczek leku w układzie pokarmowym czy krażeniu (HUANG i współaut. 2015). Oprócz chemioterapeutyków i sterydów (HUANG i współaut. 2015), lipoproteiny moga dostarczać do komórek cząsteczki kwasów nukleinowych i krótkie fragmenty peptydów. Te właściwości sa wykorzystywane m.in. w opracowywaniu skuteczniejszych preparatów przeciwko retro- (wirus HIV), mykso-, filoczy koronawirusom. Dołączanie czasteczek cholesterolu zwiększa także potencjał terapeutyczny powstajacych, bądź będacych już w obiegu klinicznym preparatów antywirusowych (np. immunoadhezyn czy peptydowych inhibitorów fuzji wirusa) (PESSI 2015, URBANOWICZ i współaut. 2015).

Zatem „dwie twarze" cholesterolu stwarzaja problemy, ale jednocześnie otwieraja nowe możliwości wykorzystania go jako markera diagnostycznego i celu terapeutycznego.

Streszczenie

Cholesterol to cząsteczka zbudowana $z$ 17-węglowej struktury cyklopentanoperhydrofenantrenu i dołączonego do niej 6-węglowego łańcucha bocznego, klasyfikowana jako alkohol steroidowy ze względu na obecność pojedynczej grupy hydroksylowej. Główną funkcją cholesterolu jest zależna od temperatury modulacja płynności błon komórkowych. Duża ilość cholesterolu występuje w nanodomenach błonowych (tratwach lipidowych i kaweolach), które pełnia ważna rolę $\mathrm{w}$ procesie endocytozy i przekaźnictwie międzykomórkowym. Ponadto, jest on prekursorem hormonów steroidowych produkowanych przez gonady i kore nadnerczy oraz warunkuje właściwy przebieg rozwoju embrionalnego. Poza pełnieniem istotnej roli fizjologicznej, cholesterol może przyczyniać się do rozwoju wielu stanów patologicznych, wynikających zarówno $\mathrm{z}$ nagromadzenia jego cząsteczek w ustroju, jak i zaburzeń ich metabolizmu. Jego udział opisano m.in. w rozwoju schorzeń neurodegeneracyjnych, chorób układu krążenia, chorób nerek oraz chorób nowotworowych. Obecnie prowadzone badania zmierzaja do opracowania nowych strategii terapeutycznych, pozwalających na skuteczniejsza i bezpieczniejsza kontrole poziomu cholesterolu i regulację jego metabolizmu, oraz majacych na celu wykorzystanie cholesterolu jako składnika nowych, skuteczniejszych leków.

\section{LITERATURA}

Anderson J. L., Gautier T., Niustad N., Tölle M., SCHUCHARDT M., VAN DER GIET M., TIETGE U. J., 2016. High density lipoprotein (HDL) particles from end-stage renal disease patients are defective in promoting reverse cholesterol transport. Sci. Rep. 7, 41481.

BAARDMAN M. E., KERSTJENS-FREDERIKSE W. S., BERgER R. M., BAKKer M. K., HOFSTRA R. M., PLÖSCH T., 2013. The role of maternal-fetal cholesterol transport in early fetal life: current insights. Biol. Reprod. 88, 1-9.

BAEK A. E., NELSON E. R., 2016. The contribution of cholesterol and its metabolites to the pathophysiology of breast cancer. Horm. Cancer. 7, 219-228.

BHATT A., Rohatgi A., 2016. HDL cholesterol efflux capacity: cardiovascular risk factor and potential therapeutic target. Curr. Atheroscler. Rep. 18, 1-8.

Blom T., SOMERHARJu P., IKonen E., 2011. Synthesis and biosynthetic trafficking of membrane lipids. Cold Spring Harb. Perspect. Biol. 3, 1-17.

ButTERFIELD D. A., BARONE E., MANCUso C., 2011. Cholesterol-independent neuroprotective and neurotoxic activities of statins: perspectives for statin use in Alzheimer disease and other age-related neurodegenerative disorders. Pharmacol. Res. 64, 180-186.

CAÑUETO J., GIRÓS M., GONZÁlEZ-SARMIENTO R., 2014. The role of the abnormalities in the distal pathway of cholesterol biosynthesis in the Conradi-Hünermann-Happle syndrome. Biochim. Biophys. Acta 1841, 336-344.

COOPER M. K., WASSIF C. A., KRAKOWIAK P. A., TAipale J., Gong R., Kelley R. I., PORTER F. D., BEACHY P. A., 2003. A defective response to Hedgehog signaling in disorders of cholesterol biosynthesis. Nat. Genet 33, 508-513.

DE MEYer F., SMit B., 2009. Effect of cholesterol on the structure of a phospholipid bilayer. Proc. Natl. Acad. Sci. USA 106, 3654-3658.

Di ViziO D., SOlOMON K. R., FREEMAN M. R., 2008. Cholesterol and cholesterol-rich membranes in prostate cancer: an update. Tumori 94, 633-639.

Doria M., Maugest L., Moreau T., Lizard G., VEJUX A., 2016. Contribution of cholesterol 
and oxysterols to the pathophysiology of Parkinson's disease. Free Radic. Biol. Med. 101, 393-400.

DRZEWIŃSKA J., PUŁASKI L., SOSZYŃSKI M., BARTOSZ G., 2009. Seladyna 1/DHCR24: główne białko homeostazy komórkowej $i$ biosyntezy cholesterolu. Post. Hig. Med. Dosw. 63, 318-330.

DURRINGTON P. N., 2007. Lipoproteins and their metabolism. [W:] Hyperlipidaemia. diagnosis and management. DURRINGTON P. N. (red.). Hodder Arnold, London, 19-65.

Elshourbagy N. A., MEYers H. V., ABDEL-MEGUID S. S., 2014. Cholesterol: the good, the bad, and the ugly - therapeutic targets for the treatment of dyslipidemia. Med. Princ. Pract. 23, 99-111.

FEDORYSZAK-KuŚKA N., PANASIEWICZ M., PACUSZKA T., 2011. Tratwy lipidowe - obserwacje $i$ watpliwości. Post. Biol. Kom. 38, 313-332.

FREEMAN M. R., CinAR B., KIM J., MUKHOPADHYAY N. K., Di Vizio D., AdAM R. M., SOlOMON K. R., 2007. Transit of hormonal and EGF receptor-dependent signals through cholesterol-rich membranes. Steroids 72, 210-217.

Gargiulo R., Suhail F., LERMA E. V., 2016. Cardiovascular disease and chronic kidney disease. Dis. Mon. 61, 403-413.

GBUREK J., GOŁAB K., KonopsKA B., 2015. Endocytoza niezależna od klatryny - rola $w$ patomechanizmie chorób i aspekty farmaceutyczne. Post. Hig. Med. Dośw. 69, 763-776.

GOŹDZIKIEWICZ I., GNIOT-SZULŻYCKA J., 2004. Mechanizm konwersji cholesterolu do pregenolonu udziłem mitochondrialnego kompleksu desmolazy. Kosmos 53, 133-145.

GROULEFF J., IRUDAYAM S. J., SKEBY K. K., ScHIØтT B., 2015. The influence of cholesterol on membrane protein structure, function, and dynamics studied by molecular dynamics simulations. Biochim. Biophys. Acta 1848, 17831795.

GuY J., Hendrich B., Holmes M., Martin J. E., BIRD A., 2001. A mouse Mecp2-null mutation causes neurological symptoms that mimic Rett syndrome. Nat. Genet. 27, 322-326.

Haynes R., LEWIS D., EMBERSON J., ReITH C., Agodoa L., CASS A., CRAIG J. C., DE ZEeUW D., Feldt-Rasmussen B., Fellstrom B., LeVin A., WheEler D. C., Walker R., HerRingtoN W. G., Baigent C., LandRaY M. J., 2014. Ef fects of lowering $L D L$ cholesterol on progres sion of kidney disease. Clin. Epidemiol. 25, $1822-1833$

Head B. P., Patel H. H., Insel P. A., 2014. Interaction of membrane/lipid rafts with the cytoskeleton: impact on signaling and function: membrane/lipid rafts, mediators of cytoskeletal arrangement and cell signaling. Biochim. Biophys. Acta 1838, 532-545. HEBANOWSKA A., 2010. Biosynteza kwasów żółciowych $i$ ich jej regulacja. Post. Hig. Med. Dośw. 65, 544554.

Honda H., Hirano T., UEda M., KoJima S., MaSHIBA S., YASUYUKI H., MichiHATA T., SHIBATA T., 2016. High-density lipoprotein subfractions and their oxidized subfraction particles in patients with chronic kidney disease. J. Atheroscler. Thromb. 23, 81-94.

HUANG H., CRUZ W., CHEN J., ZHENG G., 2015 Learning from biology: synthetic lipoproteins for drug delivery. Wiley Interdisciplinary Reviews: Nanomed. Nanobiotechnol. 7, 298-314.

KANIA E., PAJAKK B., GAJKOWSKA B., ORZECHOWSKI A., 2012. Tratwy lipidowe $w$ chorobie Alzheimer'a. Post. Bioch. 58, 209-216.
KON V., YANG H., FAZIO S., 2015. Residual cardiovascular risk in chronic kidney disease: role of high-density lipoprotein. Arch. Med. Res. 46, 379-391.

KonTUREK S., 2007. Układ trawienny. [W:] Fizjologia czlowieka $z$ elementami fizjologii stosowanej $i$ klinicznej. TRACZYK W.Z., TRZEBSKI A., GODLEWSKI A. Wydawnictwo Lekarskie PZWL, Warszawa, 798.

KORDOWIAK A. M, KORDOWIAK S., 2011. Tratwy lipidowe - mikrodomeny błon biologicznych. Post. Biol. Kom. 38, 231-245.

Kovtun O., Tillu V. A., Ariotti N., Parton R. G., Collins B. M., 2015. Cavin family proteins and the assembly of caveolae. J. Cell Sci. $128,1269-1278$

KOWALSKI A., KRIKORIAN A., LERMA E. V., 2015. Dyslipidemia in chronic kidney disease. Dis. Mon. 61, 396-402.

KRAEMER F. B., KHOR V. K., SHEN W. J., AZHAR S., 2013. Cholesterol ester droplets and steroidogenesis. Mol. Cell. Endocrinol. 22, 37153719.

KUCHARSKA E., 2014. Miażḋ̇yca tętnic-wybrane aspekty. Przegl. Lek. 7, 400-402.

KWIATKOWSKA K., SoBOTA A., 2004. Mikrodomeny błony komórkowej miejscem zapoczątkowania szlaków sygnałowych przez immunoreceptory. Kosmos 53, 113-122.

Martin M. G., Pfrieger F., DotTi C. G., 2014. Cholesterol in brain disease: sometimes determinant and frequently implicated. EMBO Rep. 15, 1036-1052.

MASsY Z. A., DE ZEEUW D., 2013. LDL cholesterol in CKD-treat or not to treat. Kidney Int. 84, 451-456.

MaUliK M., WestawaY D., Jhamandas J. H., KaR S., 2013. Role of cholesterol in APP metabolism and its significance in Alzheimer's disease pathogenesis. Mol. Neurobiol. 47, 37-63.

MESMIN B., MAXFIELD F. R., 2009. Intracellular sterol dynamics. Biochim. Biophys. Acta 1791, 636-645.

MilleR W. L., 2013. Steroid hormone synthesis in mitochondria. Mol. Cell. Endocrinol. 379, 6273.

MilleR W. L., Auchus R. J., 2011. The molecular biology, biochemistry, and physiology of human steroidogenesis and its disorders. Endocrinol. Rev. 32, 81-151.

MilleR W. L., Bose H. S., 2011. Early steps in steroidogenesis: intracellular cholesterol trafficking. J. Lipid Res. 52, 2111-2135.

MURAI T., 2012. The role of lipid rafts in cancer cell adhesion and migration. Int. J. Cell Biol. 2012, 763283.

MURAI T., 2015. Cholesterol lowering: role in cancer prevention and treatment. Biol. Chem. 396, $1-11$.

Paila Y. D., ChatTopadhyay A., 2010. Membrane cholesterol in the function and organization of G-protein coupled receptors. Subcell. Biochem. 51, 439-466.

PASIERSKI T., GACIONG Z., 2004. Rozwój i regresja miażdżycy. [W:] Angiologia. PASIERSKI T, GACIONG Z., TORBICKI A. (red.). Wydawnictwo Lekarskie PZWL, Warszawa, 50-58.

Pelton K., Freeman M. R., Solomon K. R., 2012. Cholesterol and prostate cancer. Curr. Opin. Pharmacol. 12, 751-759.

PERI A., 2016. Neuroprotective effects of estrogens: the role of cholesterol. J. Endocrinol. Invest. $39,11-18$

PESSI A., 2015. Cholesterol-conjugated peptide antivirals: a path to a rapid response to emerging viral diseases. J. Pept. Sci. 21, 379-86. 
Peters S. A., Singhateh Y., Mackay D., HuXley R. R., WOODWARD M., 2016. Total cholesterol as a risk factor for coronary heart disease and stroke in women compared with men: A systematic review and meta-analysis. Atherosclerosis 248, 123-131.

PoIrier J., Miron J., PiCARD C., Gormley P., Théroux L., Breitner J., DEA D., 2014. Apolipoprotein $E$ and lipid homeostasis in the etiology and treatment of sporadic Alzheimer's disease. Neurobiol. Aging. 35, 3-10.

PRZYBYŁO M., JANIK M. E., SZAJDA S. D., MINAROWSKI Ł., WASZKIEWICZ N., HOJA-ŁUKOWICZ D., 2016. Promieniowanie ultrafioletowe: $O$ co tyle hałasu? [W:] Zapobieganie chorobom nowotworowym. SZAJDA S. D., WASZKIEWCZ N., ZWIERZ K., ŁADNY J. R. (red.). Wyższa Szkoła Zawodowa Ochrony Zdrowia Towarzystwa Wiedzy Powszechnej w Łomży, Łomża, 40-67.

Ribas V., García-Ruiz C., FERnándeZ-CheCA J. C. 2016. Mitochondria, cholesterol and cancer cell metabolism. Clin. Transl. Med. 5, 22.

RYSTWEJ-NiEDŹWIEDZKA P., MEKAL A., DEPTUŁA W., 2010. Komórki układu odpornościowego $w$ miażdzycy-wybrane dane. Post. Hig. Med. Dośw. 64, 417-422.

Sebastiao A. M., Colino-Olivieira M., Assaife-LoPES N., DIAS R. B., RIBEIRO J. A., 2012. Lipid rafts, synaptic transmission and plasticity: Impact in age-related neurodegenerative diseases. Neuropharmacology 64, 97-107.

SEeger M. A., PAller A. S., 2014. The role of abnormalities in the distal pathway of cholesterol synthesis in the Congenital Hemidysplasia with Ichthyosiform erythroderma and Limb Defects (CHILD) syndrome. Biochim. Biophys. Acta $1841,345-352$

Sengupta D., ChatTopadhyay A., 2015. Molecular dynamics simulations of GPCR-cholesterol interaction: An emerging paradigm. Biochim. Biophys. Acta 1848, 1775-1782.

SimONS K., SAMPAIO J. L., 2011. Membrane organization and lipid rafts. Cold Spring Harb. Perspect. Biol. 3, 1-18.

SKOCZYŃSKA A., 2005. Rola lipidów w powstawaniu miażḋ̇ycy. Post. Hig. Med. Dośw. 59, 346-357.

Song Y., Kenworthy A. K., SAnders C. R., 2014. Cholesterol as a co-solvent and a ligand for membrane proteins. Prot.Sci. 23, 1-22.
STRYER L., 2003. Biosynteza elementów budulcowych. [W:] Biochemia. Augustyniak J., MICHEJDA J. (red.). Wydawnictwo Naukowe PWN, Warszawa, 738-754.

Sun J. H., YU J. T., TAN L., 2015. The role of cholesterol metabolism in Alzheimer's disease. Mol. Neurobiol. 51, 947-965.

Thurm A., Tierney E., Farmer C., Albert P., JoSEPH L., SWEdo S., BiAnCONI S., BukELIS I., WheEler C., SARPhare G., LANHAM D., WASSI C. A., PORTER F. D., 2016. Development, behavior and biomarker characterization of Smith-Lemli-Opitz syndrome: an update. J. Neurodev. Disord. 8, 1-10.

TURGEON R. D., BARRY A. R., PEARSON G. J., 2016. Familial hypercholesterolemia. Review of diagnosis, screening, and treatment. Can. Fam. Physician.62, 32-37.

URBANOWICZ R. A., LACEK K., LAHM A., BienKowsKA-SZEWCZYK K., BALL J. K., NICOSIA A., CORTESE R., PESSI A., 2015. Cholesterol conjugation potentiates the antiviral activity of an HIV immunoadhesin. J. Pept. Sci. 21, 743-749.

VANCE J. E., KARTEN B., 2014. Niemann-Pick C disease and mobilization of lysosomal cholesterol by cyclodextrin. J. Lipid Res. 55, 16091621.

VAZIRI N. D., NORRIS K., 2011. Lipid disorders and their relevance to outcomes in chronic kidney disease. Blood Purif. 31, 189-196.

WOLOZIN B., 2004. Cholesterol and the Biology of Alzheimer's Disease. Neuron 41, 7-10.

Xue-Shan Z., Peng J., Qi W., Zhong R., Li-Hong P., ZHI-HAN T., ZHI-SHENG J., GUI-XUE W., LUSHAN L., 2016. Imbalanced cholesterol metabolism in Alzheimer's disease. Clin. Chim. Acta 456, 107-114.

YAN G., Li L., ZHU B., LI Y., 2016. Lipidome in colorectal cancer. Oncotarget 7, 33429-33439.

ZAWIŚLAK B., MARCHLEWICZ M., ŚWIDER-AL-AMAWI M., WENDA-RÓŻEWICKA L., WISZNIEWSKA B., 2010. Skóra $i$ jej udział $w$ syntezie hormonów steroidowych. Post. Biol. Kom. 37, 783-793.

ZuWAEA-JAGIEŁŁO J., 2004. Rola kaweoli śródbłon$k a w$ endocytozie późnych produktów glikacji. Post. Bioch. 50, 272-281. 
KOSMOS Vol. 67, 2, 375-390, 2018

Maria Użarowska, Magdalena SuRman, Marcelina JaniK

Department of Glycoconjugate Biochemistry, Institute of Zoology and Biomedical Research, Faculty of Biology, Jagiellonian University

in Kraków, 9 Gronostajowa Str., 30-387 Kraków,E-mail:maria.uzarowska@student.uj.edu.pl,

magdalena.surman@doctoral.uj.edu.pl, marcelina.janik@uj.edu.pl

TWO FACES OF CHOLESTEROL: PHYSIOLOGICAL IMPORTANCE AND ROLE IN DISEASE PATHOGENESIS

\section{Summary}

Cholesterol is a molecule build of 17-carbon cyclopentano-perhydro-phenanthrene structure and 6- carbon side chain, classified as steroid alcohol due to the presence of a single hydroxyl group. The main function of cholesterol is temperature-dependent modulation of cell membrane liquidity. Large amounts of cholesterol are found in membrane nanodomains (lipid rafts and caveolae) that are essential for endocytosis and intercellular signaling. Moreover, cholesterol is a substrate in steroid hormones biosynthesis in gonads and adrenal glands, and determines the proper course of embryonic development. Besides its physiological role, cholesterol may contribute to pathogenesis of different diseases, resulting from its accumulation in the system or from metabolic disorders. The significance of cholesterol has already been described in several neurodegenerative disorders, cardiovascular and renal diseases, and in cancer. Therefore, current research focus on providing some new therapeutic strategies, allowing for cholesterol level control, regulation of its metabolism, or for using cholesterol molecules as effective drug component.

Keywords: cancer, cardiovascular diseases, cholesterol, chronic kidney disease, lipoproteins, neurodegenerative diseases 